\title{
The Liquidity of Chinese Listed Commercial Banks based on Net Stable Funding Ratio
}

\author{
Zhao Xueting \& Zhu Lin \\ China Postal Savings Bank \\ Beijing Branch \\ Risk Management Department
}

\begin{abstract}
Based on the requirements of BCBS (2014) for calculating the net stable financing ratio and the balance sheet of Chinese listed commercial banks, this paper calculates the net stable funding ratio of Chinese listed commercial banks, reflects the liquidity level of Chinese listed banks from the perspective of financing stability, and compares the liquidity differences among different banks. The paper finds that the liquidity level of listed commercial banks in China has been declining, and the liquidity of different types of listed commercial banks in China is quite different. Among them, listed state-owned commercial banks have the highest long-term financing stability, followed by listed joint-stock commercial banks and city commercial banks.
\end{abstract}

Keywords: Net Stable Funding Ratio; Chinese Listed Commercial Banks; Bank liquidity

\section{Introduction}

Liquidity is the basic guarantee for the normal operation of commercial banks. Liquidity risk is also the most complicated and deadly risk in the operation of commercial banks. It plays an important role in bank failures and financial crisis. For example, the financial crisis broke out in the United States, Japan and Europe. In particular, during the 2008 U.S. financial crisis, many banks went bankrupt due to insufficient liquidity, resulting in liquidity depletion in a very short period of time in the entire market, causing a serious blow to the global financial markets and the real economy.

In mid-June 2013, Chinese banking industry experienced a phased liquidity crunch. The China interbank overnight repo rate has reached $30 \%$, and the seven-day repo rate has reached $28 \%$, the overnight offered rate has rose from a low of $2.11 \%$ on may 12 th to a dangerous high of $13.44 \%$ on June 20th. However, the liquidity risk indicators of Chinese banking industry in 2013 all meet the requirements of the Chinese banking regulatory body, but there is still a phased liquidity crunch in a very short period of time. So far, the Chinese banking regulatory body has paid more attention to the liquidity risk of banks, and issued the "Commercial Bank Liquidity Risk Management Measures", pointing out that since July 1, 2018, China has measured the liquidity risk of banks through three quantitative indicators: the ratio of net stable capital, the adequacy of high-quality liquidity assets and the matching ratio of liquidity, and the regulatory requirements of these indicators are not less than $100 \%$.

\section{Literature review}

The measurement of bank liquidity risk is the basis of the research on bank liquidity risk. The measurement of commercial bank liquidity risk can be divided into direct method and indirect method according to their acquisition methods. Among them, the direct method refers to the bank liquidity risk indicators which can be obtained directly from the financial statements made public by banks. Liquidity risk indicators often used in direct method include liquidity ratio, loan-to-deposit ratio, liquidity gap, core debt ratio, liquidity covered ratio, net steady finance ratio and so on. Indirect method refers to the indicators which can reflect the liquidity risk of the bank, which is obtained by the way other than the public disclosure of the bank. The common literature of indirect method is to improve the liquidity risk indicator of commercial bank obtained by direct method, and get the new indicator to reflect the liquidity risk. The other is to make use of multifaceted information comprehensively to get a comprehensive indicator reflecting liquidity risk. Most of the literatures use the direct method to measure the bank liquidity risk. For example, Peng Jiangang, Wang Wei, Zou Ke (2014) used the liquidity gap of commercial banks to study the problem of maturity mismatch of bank deposits and loans. 
Zhang Cheng, Han Wanghong (2013) and Zhang Xuelan and He Dexu (2012) used the liquidity ratio of commercial banks to study the problem of bank risk-sharing. Lian Yonghui and Zhang Lin (2015) used the loanto-deposit ratio, net stable financing ratio and the core financing ratio index proposed by the New Zealand Central Bank to study the impact of bank liquidity risk on the size of bank credit.

Another part of the literature uses the indirect method to measure the bank liquidity risk. For example, Liu Yan, Gong Changliang (2010), Fu Qiang, Liu Xing, Ji Fang (2013) and Liu Xiaoxing (2017) studied the liquidity risk evaluation indicator of listed commercial banks through indirect methods. Among them, Liu Yan and Gong Changliang (2010) set up a commercial bank liquidity risk evaluation indicator system by R cluster analysis, and used entropy method to determine the indicator weight and rate the commercial bank liquidity risk. Fu Qiang, Liu Xing and Ji Fang (2013) constructed a comprehensive integrated liquidity risk indicator by using the method of maximizing variance combination weight and using ten liquidity risk indicators. On the integration of multidimensional liquidity risk, Liu Xiaoxing (2017) calculated the dynamic weight of different dimensions by multidimensional time-varying Copula function and entropy method to depict the dynamic correlation between different time and different dimensions of liquidity risk.

None of the liquidity risk measures in the literature above can reflect the maturity mismatch of banks, and they do not fully consider the impact of the asset-liability structure of banks on bank liquidity. Therefore, since the 2008 financial crisis, many scholars have used the latest liquidity risk indicators LCR and NSFR proposed by Basel commission to measure the bank liquidity risk. For example, Hong, Huang, Wu (2014), Abdul-Rahman, Sulaiman, Said (2017), Giordana, Schumacher (2013), Wei X, Gong Y, Wu H M (2017) and Pan Min, Tao Yuou, Wang Yi (2017). In accordance with the above literature, this paper measures the NSFR of Chinese commercial banks to reflect the financing stability and maturity mismatch of Chinese banking industry, and compares the liquidity risk characteristics of different commercial banks to reflect the real liquidity level of Chinese banking industry.

\section{Selection of data and indicators}

\section{(I) Data selection}

As China Post Office Saving Bank listed in the second half of 2016, the amount of data is relatively short, the listed commercial banks in this paper do not include the Post Office Saving Bank. Agricultural Bank of China and China Everbright Bank listed in the second half of 2010, and Agricultural Bank of China and China Everbright Bank have a large amount of assets, so this paper sets the measurement range from 2011 to 2016. The data comes from the Bankscope database.

\section{(II) Indicator selection}

In the period of post financial crisis, in order to enhance the ability of commercial banks to resist liquidity risk shocks in the international arena, the Basel commission adopted the new regulatory framework of liquidity risk as part of the "Basel Agreement III" regulatory reform plan, and issued on 16 December 2010. "Basel Agreement III" introduced liquidity covered ratio (LCR) and the net steady finance ratio (NSFR) as two liquidity indicators to better monitor liquidity risk in the financial system.

As a measure of capital stability, the net steady finance ratio (NSFR) mainly measures the liquidity risk management ability of banks over a long period of time, which requires banks to have stable financing liquidity under continuous pressure, ensures that banks can survive for more than a year under long-term liquidity risk. The NSFR is defined as the ratio of available stable fund (ASF) and the required stable fund (RSF). The NSFR aims to ensure that commercial banks have a stable source of capital within a year under continuous pressure, which means that banks have a year to restore their liquidity to a safe level. The Basel commission requires commercial banks to have a net steady finance ratio of no less than 1 in regulatory practice.

The formula for NSFR is as follows:

$$
\mathrm{NSFR}=\frac{\text { Avai I abl e St abl e Fund }(A S F)}{\text { Requi red St abl e Fund }(R S F)} \geq 100 \%
$$

The calculation of NSFR needs to give different conversion coefficients according to the specific conditions of assets and liabilities, so as to calculate the available stable funds and the required stable funds. Therefore, the calculation of NSFR not only has higher requirements for bank balance sheet, but also has unified provisions for specific conversion coefficients. Because BCBS (2014) is the newest and most detailed standard for calculating NSFR, it is also the basis of this paper. 


\section{Empirical research}

The Basel commission requires that the numerator ASF (available stable assets) of the NSFR formula include the following categories: (1) capital; (2) debt with a maturity of one year or more; (3) preferred stock with a maturity of one year or more; (4) deposits with no fixed maturity date, and the term deposits held at the institution for less than one year, but in the event of extreme pressure on the bank; (5) wholesale financing with held at the institution for less than one year, but in the event of extreme pressure on the bank. The ASF is designed to ensure a stable source of financing for banks under extreme event pressures, so as to provide 1 years of adjustment and recovery time for banks to cope with extreme pressure events.

The calculation of the net steady finance ratio (NSFR) of each bank involves a large amount of bank financial statement data. In the working paper of IMF, according to the stipulation of BCBS (2014) for calculating NSFR, Gobat, Yanase, Maloney (2014) pointed out how to use Bankscope database to calculate NSFR. Gobat, Yanase, Maloney (2014) gave a detailed explanation of how to use the database to measure NSFR. Next, the bank balance sheet data provided by Bankscope database is used to measure the ASF, RSF and NSFR of listed commercial banks in China.

According to the requirement of conversion rate in the final revised draft of BCBS (2014) and the availability of balance sheet information in China, this paper calculates the available stable funds and the required stable funds by the business of all listed commercial banks in China. The available stable fund of bank comes from its own liabilities and equity projects, of which liabilities projects include current account deposits, savings deposits and term deposits, with weights of 0.9, 0.95 and 0.95 , respectively; the weight for long-term debt is 1; and the weight for equity items is 1 . The required stable fund by the bank comes from their own asset projects. The weights are set as follows: the weight of all bank loans and advances is 0.85 ; the weight of government bonds in other profitable assets is 0.05 ; the weight of the remaining bonds excluding government bonds and derivative assets is 0.5; the weight of off-balance sheet items is 0.05 ; the weight of cash and interbank deposit is 0 ; the weight of fixed assets, goodwill and other intangible assets is 1 .

Table 1 ASF of Chinese Listed Commercial Banks (unit: 1000 yuan)

\begin{tabular}{l|l|l|l|l|l|l}
\hline ASF & 2011 & 2012 & 2013 & 2014 & 2015 & 2016 \\
\hline ICBC & $1.96 \mathrm{E}+10$ & $2.19 \mathrm{E}+10$ & $2.34 \mathrm{E}+10$ & $2.51 \mathrm{E}+10$ & $2.69 \mathrm{E}+10$ & $2.93 \mathrm{E}+10$ \\
\hline CCB & $1.59 \mathrm{E}+10$ & $1.82 \mathrm{E}+10$ & $1.95 \mathrm{E}+10$ & $2.10 \mathrm{E}+10$ & $2.26 \mathrm{E}+10$ & $2.56 \mathrm{E}+10$ \\
\hline ABC & $1.47 \mathrm{E}+10$ & $1.68 \mathrm{E}+10$ & $1.81 \mathrm{E}+10$ & $1.95 \mathrm{E}+10$ & $2.14 \mathrm{E}+10$ & $2.38 \mathrm{E}+10$ \\
\hline BOC & $1.39 \mathrm{E}+10$ & $1.51 \mathrm{E}+10$ & $1.65 \mathrm{E}+10$ & $1.80 \mathrm{E}+10$ & $1.92 \mathrm{E}+10$ & $2.12 \mathrm{E}+10$ \\
\hline BCM & $5.61 \mathrm{E}+09$ & $6.38 \mathrm{E}+09$ & $7.14 \mathrm{E}+09$ & $7.26 \mathrm{E}+09$ & $8.18 \mathrm{E}+09$ & $9.06 \mathrm{E}+09$ \\
\hline CIB & $2.42 \mathrm{E}+09$ & $3.23 \mathrm{E}+09$ & $3.74 \mathrm{E}+09$ & $4.21 \mathrm{E}+09$ & $5.10 \mathrm{E}+09$ & $5.97 \mathrm{E}+09$ \\
\hline CMB & $3.58 \mathrm{E}+09$ & $4.23 \mathrm{E}+09$ & $4.72 \mathrm{E}+09$ & $5.61 \mathrm{E}+09$ & $6.23 \mathrm{E}+09$ & $6.68 \mathrm{E}+09$ \\
\hline CITICIB & $3.29 \mathrm{E}+09$ & $3.67 \mathrm{E}+09$ & $4.39 \mathrm{E}+09$ & $4.85 \mathrm{E}+09$ & $5.67 \mathrm{E}+09$ & $6.52 \mathrm{E}+09$ \\
\hline CMBC & $2.75 \mathrm{E}+09$ & $3.54 \mathrm{E}+09$ & $3.78 \mathrm{E}+09$ & $4.51 \mathrm{E}+09$ & $5.14 \mathrm{E}+09$ & $6.18 \mathrm{E}+09$ \\
\hline SPD & $2.91 \mathrm{E}+09$ & $3.38 \mathrm{E}+09$ & $3.95 \mathrm{E}+09$ & $4.44 \mathrm{E}+09$ & $5.38 \mathrm{E}+09$ & $5.76 \mathrm{E}+09$ \\
\hline CEB & $1.83 \mathrm{E}+09$ & $2.29 \mathrm{E}+09$ & $2.35 \mathrm{E}+09$ & $2.72 \mathrm{E}+09$ & $3.06 \mathrm{E}+09$ & $3.62 \mathrm{E}+09$ \\
\hline HABC & $1.24 \mathrm{E}+09$ & $1.61 \mathrm{E}+09$ & $1.87 \mathrm{E}+09$ & $2.27 \mathrm{E}+09$ & $2.61 \mathrm{E}+09$ & $3.05 \mathrm{E}+09$ \\
\hline BOB & $1.35 \mathrm{E}+09$ & $1.57 \mathrm{E}+09$ & $1.77 \mathrm{E}+09$ & $1.97 \mathrm{E}+09$ & $2.14 \mathrm{E}+09$ & $2.39 \mathrm{E}+09$ \\
\hline BON & $1.07 \mathrm{E}+09$ & $1.24 \mathrm{E}+09$ & $1.46 \mathrm{E}+09$ & $1.62 \mathrm{E}+09$ & $1.93 \mathrm{E}+09$ & $2.22 \mathrm{E}+09$ \\
\hline NBCB & $2.92 \mathrm{E}+08$ & $3.68 \mathrm{E}+08$ & $4.53 \mathrm{E}+08$ & $6.29 \mathrm{E}+08$ & $8.64 \mathrm{E}+08$ & $1.18 \mathrm{E}+09$ \\
\hline
\end{tabular}

Note: Ningbo Bank lacks relevant information in its financial reports for 2011 and 2012, so it is impossible to measure its ASF. By measuring the balance sheet data of China's listed commercial banks, Table 1 shows the long-term available stable fund (ASF) generated by all listed commercial banks in China. From Table 1, we can see that the amount of available stable fund of China's listed commercial banks is increasing every year, and the available stable fund of each bank is directly proportional to the scale of bank assets. The available stable funds of listed state-owned commercial banks are much larger than those of listed joint-stock commercial banks and listed city commercial banks. The available stable funds of listed joint-stock commercial banks are larger than the available stable funds of listed city commercial banks. 
Therefore, in the face of extreme pressure events, the state-owned commercial banks have more capital to withstand risks than listed joint-stock commercial banks and listed city commercial banks. Whether banks can survive extreme stress events, however, depends not only on its long-term and stable financing, but also on the long-term and stable capital needed for its business. So, the Basel commission requires that the long-term available stable funds of banks should at least meet the needs of long-term required stable funds by business, so as to achieve a one-year adjustment and recovery time in the face of extreme pressure events.

According to the requirements of calculation, Table 2 is the long-term required stable capital (RSF) for the business of all listed commercial banks in China, which is estimated by using the balance sheet data of listed commercial banks in China. As can be seen from Table 2, the trend of RSF and ASF performance of China banks is the same, that is, the amount of required stable fund by the business is increasing year by year. The larger the assets of a bank, the more long-term stable fund it needs to maintain business stability. Therefore, the stable fund required by the listed state-owned commercial banks is far greater than that of the listed joint-stock commercial banks and the listed city commercial banks.

Table 2 RSF of Chinese Listed Commercial Banks (unit: 1000 yuan)

\begin{tabular}{l|l|l|l|l|l|l}
\hline RSF & 2011 & 2012 & 2013 & 2014 & 2015 & 2016 \\
\hline ICBC & $1.60 \mathrm{E}+10$ & $1.81 \mathrm{E}+10$ & $1.95 \mathrm{E}+10$ & $2.11 \mathrm{E}+10$ & $2.28 \mathrm{E}+10$ & $2.57 \mathrm{E}+10$ \\
\hline CCB & $1.27 \mathrm{E}+10$ & $1.44 \mathrm{E}+10$ & $1.59 \mathrm{E}+10$ & $1.73 \mathrm{E}+10$ & $1.89 \mathrm{E}+10$ & $2.13 \mathrm{E}+10$ \\
\hline ABC & $1.17 \mathrm{E}+10$ & $1.33 \mathrm{E}+10$ & $1.47 \mathrm{E}+10$ & $1.62 \mathrm{E}+10$ & $1.81 \mathrm{E}+10$ & $1.99 \mathrm{E}+10$ \\
\hline BOC & $1.19 \mathrm{E}+10$ & $1.28 \mathrm{E}+10$ & $1.40 \mathrm{E}+10$ & $1.55 \mathrm{E}+10$ & $1.71 \mathrm{E}+10$ & $1.83 \mathrm{E}+10$ \\
\hline BCM & $4.67 \mathrm{E}+09$ & $5.34 \mathrm{E}+09$ & $6.09 \mathrm{E}+09$ & $6.42 \mathrm{E}+09$ & $7.40 \mathrm{E}+09$ & $8.71 \mathrm{E}+09$ \\
\hline CIB & $2.42 \mathrm{E}+09$ & $3.29 \mathrm{E}+09$ & $3.88 \mathrm{E}+09$ & $4.84 \mathrm{E}+09$ & $6.38 \mathrm{E}+09$ & $7.47 \mathrm{E}+09$ \\
\hline CMB & $2.86 \mathrm{E}+09$ & $3.45 \mathrm{E}+09$ & $4.17 \mathrm{E}+09$ & $4.96 \mathrm{E}+09$ & $5.87 \mathrm{E}+09$ & $6.27 \mathrm{E}+09$ \\
\hline CITICIB & $2.77 \mathrm{E}+09$ & $3.02 \mathrm{E}+09$ & $3.81 \mathrm{E}+09$ & $4.50 \mathrm{E}+09$ & $5.72 \mathrm{E}+09$ & $6.55 \mathrm{E}+09$ \\
\hline CMBC & $2.17 \mathrm{E}+09$ & $3.17 \mathrm{E}+09$ & $3.22 \mathrm{E}+09$ & $4.11 \mathrm{E}+09$ & $4.71 \mathrm{E}+09$ & $6.51 \mathrm{E}+09$ \\
\hline SPD & $2.69 \mathrm{E}+09$ & $3.21 \mathrm{E}+09$ & $3.91 \mathrm{E}+09$ & $4.61 \mathrm{E}+09$ & $5.78 \mathrm{E}+09$ & $6.64 \mathrm{E}+09$ \\
\hline CEB & $1.73 \mathrm{E}+09$ & $2.41 \mathrm{E}+09$ & $2.53 \mathrm{E}+09$ & $2.88 \mathrm{E}+09$ & $3.43 \mathrm{E}+09$ & $4.42 \mathrm{E}+09$ \\
\hline PABC & $1.29 \mathrm{E}+09$ & $1.68 \mathrm{E}+09$ & $1.99 \mathrm{E}+09$ & $2.31 \mathrm{E}+09$ & $2.65 \mathrm{E}+09$ & $3.15 \mathrm{E}+09$ \\
\hline HB & $1.24 \mathrm{E}+09$ & $1.49 \mathrm{E}+09$ & $1.74 \mathrm{E}+09$ & $1.92 \mathrm{E}+09$ & $2.02 \mathrm{E}+09$ & $2.45 \mathrm{E}+09$ \\
\hline BOB & $9.85 \mathrm{E}+08$ & $1.17 \mathrm{E}+09$ & $1.40 \mathrm{E}+09$ & $1.60 \mathrm{E}+09$ & $1.95 \mathrm{E}+09$ & $2.32 \mathrm{E}+09$ \\
\hline BON & $2.99 \mathrm{E}+08$ & $3.71 \mathrm{E}+08$ & $4.86 \mathrm{E}+08$ & $6.76 \mathrm{E}+08$ & $9.64 \mathrm{E}+08$ & $1.25 \mathrm{E}+09$ \\
\hline NBCB & NA & NA & $5.02 \mathrm{E}+08$ & $6.23 \mathrm{E}+08$ & $8.46 \mathrm{E}+08$ & $1.03 \mathrm{E}+09$ \\
\hline
\end{tabular}

Note: Ningbo Bank lacks relevant information in its financial reports for 2011 and 2012, so it is impossible to measure its RSF.

According to the ASF and RSF of listed commercial banks given in Tables 1 and 2, divide the corresponding ASF and RSF, and get the NSFR of listed commercial banks in China from 2011 to 2016. As shown in Table 3, the NSFR of these banks in the sample interval is greater than 1, such as Industrial \& Commercial Bank of China, Bank for Economic Construction, Agricultural Bank, Bank Of China, Bank of Communications, China Merchants Bank, and their liquidity is relatively sufficient. The NSFR of Minsheng Bank and Hua Xia Bank from 2011 to 2015 are all more than 1, and decline year by year. The NSFR of Minsheng Bank and Hua Xia Bank is less than 1 in 2016.

The NSFR of Bank of Beijing and China Citic Bank from 2011 to 2014 is greater than 1 and declining year by year. Since 2015, the NSFR of Bank of Beijing and China Citic Bank is less than 1. Since 2014, the NSFR of Shanghai Pudong Development Bank is less than 1, liquidity is relatively inadequate. Since 2012, the NSFR of China Everbright Bank is less than 1, liquidity is relatively inadequate. The annual NSFR of Industrial Bank, Ping An Bank, Bank of Nanjing and Bank of Ningbo are all less than 1 within the sample interval. Judging from the average liquidity level, within the sample interval, the liquidity of the China's listed state-owned commercial banks and some listed joint-stock commercial banks can meet the requirements of the Basel Agreement III for NSFR greater than 1, such as China Merchants Bank, Minsheng Bank, Hua Xia Bank, Bank of Beijing. Industrial Bank, Shanghai Pudong Development Bank, China Everbright Bank, Ping An Bank, Bank of Nanjing and Bank of Ningbo failed to meet the "Basel Agreement III" requirements for NSFR greater than 1. 
Table 3 NSFR of China's Listed Commercial Banks

\begin{tabular}{l|l|l|l|l|l|l|l}
\hline Bank name & 2011 & 2012 & 2013 & 2014 & 2015 & 2016 & $\begin{array}{l}\text { average } \\
\text { value }\end{array}$ \\
\hline ICBC & 1.2219 & 1.2077 & 1.1976 & 1.1893 & 1.1804 & 1.1417 & 1.1898 \\
\hline CCB & 1.2528 & 1.2655 & 1.2301 & 1.2156 & 1.1950 & 1.2022 & 1.2269 \\
\hline ABC & 1.2589 & 1.2595 & 1.2335 & 1.2048 & 1.1795 & 1.1947 & 1.2218 \\
\hline BOC & 1.1674 & 1.1784 & 1.1800 & 1.1625 & 1.1198 & 1.1590 & 1.1612 \\
\hline BCM & 1.2012 & 1.1955 & 1.1737 & 1.1294 & 1.1055 & 1.0404 & 1.1409 \\
\hline CIB & 0.9984 & 0.9799 & 0.9642 & 0.8709 & 0.8005 & 0.7996 & 0.9023 \\
\hline CITB & 1.2537 & 1.2244 & 1.1318 & 1.1320 & 1.0610 & 1.0656 & 1.1447 \\
\hline CMBC & 1.1886 & 1.2138 & 1.1533 & 1.0782 & 0.9911 & 0.9958 & 1.1035 \\
\hline SPD & 1.2675 & 1.1167 & 1.1760 & 1.0951 & 1.0897 & 0.9503 & 1.1159 \\
\hline CEB & 1.0844 & 1.0509 & 1.0106 & 0.9627 & 0.9310 & 0.8686 & 0.9847 \\
\hline PABC & 0.9558 & 0.9497 & 0.9263 & 0.9424 & 0.8910 & 0.8195 & 0.9308 \\
\hline HB & 1.0912 & 0.9585 & 0.9379 & 0.9832 & 0.9838 & 0.9693 & 0.9652 \\
\hline BOB & 1.0814 & 1.0602 & 1.0201 & 1.0297 & 1.0625 & 0.9761 & 1.0380 \\
\hline BON & 0.9758 & 0.9928 & 0.9319 & 0.9311 & 0.8965 & 0.9492 & 0.9462 \\
\hline NBCB & NA & NA & 0.9359 & 0.9244 & 0.8339 & 0.8992 & 0.8983 \\
\hline
\end{tabular}

Note: Ningbo Bank lacks relevant information in its financial reports for 2011 and 2012, so it is impossible to measure its NSFR.

Figure 1 reflects the changes of NSFR of China's listed commercial banks from 2011 to 2016 from two dimensions: cross section and time. The horizontal axis of figure 1 is arranged in the order of listed state-owned commercial banks, listed joint-stock commercial banks and listed city commercial banks, and the vertical axis is the corresponding NSFR. On the whole, the net steady finance ratio of listed city commercial banks is lower than that of listed state-owned commercial banks and listed joint-stock commercial banks. And the net steady finance ratio of all kinds of banks is not the same. Among them, the listed joint-stock commercial banks have large differences in the net steady finance ratio of each bank, the net steady finance ratio of Industrial Bank is the lowest, followed by Shanghai Pudong Development Bank, China Everbright Bank. Among the listed state-owned commercial banks, the net steady finance ratio of Bank of Communications is slightly lower than other stateowned commercial banks. Among the listed city commercial banks, Bank of Ningbo has the lowest net steady finance ratio. From the perspective of time, most of the net steady finance ratios of listed commercial banks in China show a decreasing trend year by year, indicating that the difficulty of maintaining long-term stable financing liquidity of China listed commercial banks is relatively increased. The net steady finance ratio of banks decreased significantly in 2016 compared with 2011, and more than half of the net steady finance ratio of listed commercial banks is less than 1, which indicates that these long-term stable funds of banks is difficult to cover their long-term liabilities completely. Its balance sheet needs to be adjusted to meet regulatory requirements.

NSFR of China's Listed Commercial Banks

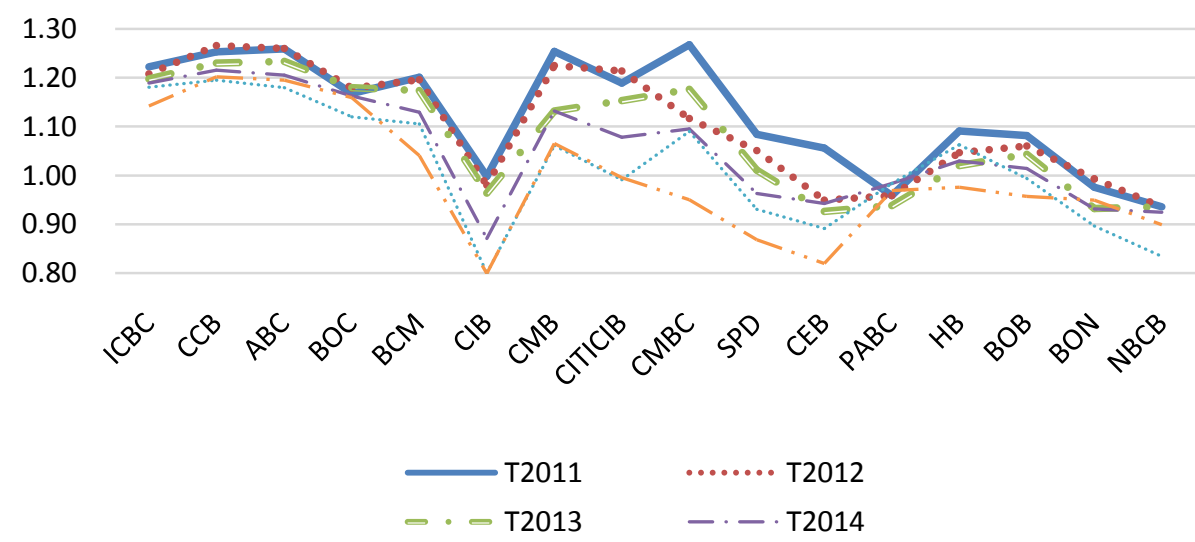

Figure 1NSFR of China's Listed Commercial Banks 
Based on the nature of the banks, the Table 4 provides a summary of the net steady finance ratios of banks and their growth rates over the years. As can be seen from Table 4, the overall NSFR of state-owned commercial banks is greater than 1, indicating that the overall liquidity of state-owned commercial banks is relatively high. Since 2015, the NSFR of listed joint-stock commercial banks has been less than 1, showing that the overall liquidity of listed joint-stock commercial banks has declined, and the NSFR of listed joint-stock commercial banks has declined faster than that of state-owned commercial banks and listed city commercial banks. The NSFR of listed city commercial banks began to decline rapidly since 2012, and began to show a lack of liquidity and continued to decline in 2013. According to the average NSFR growth rate of banks over the years, the liquidity of listed joint-stock commercial banks declined the fastest, followed by listed city commercial banks, and finally the state-owned commercial banks. Within the sample interval, the average growth rate of NSFR of all listed commercial banks in China is negative over the years.

Table 4 NSFR and its annual growth rate by bank nature

\begin{tabular}{|l|l|l|l|l|l|l|l|}
\hline NSFR & 2011 & 2012 & 2013 & 2014 & 2015 & 2016 & Average value \\
\hline State-owned & 1.2204 & 1.2213 & 1.2030 & 1.1803 & 1.1560 & 1.1476 & 1.1881 \\
\hline Joint-stock & 1.1123 & 1.0676 & 1.0400 & 1.0118 & 0.9763 & 0.9306 & 1.0231 \\
\hline City & 1.0286 & 1.0265 & 0.9705 & 0.9567 & 0.9081 & 0.9352 & 0.9566 \\
\hline Listed & 1.1372 & 1.1134 & 1.0779 & 1.0541 & 1.0197 & 0.9993 & 1.0622 \\
\hline Annual growth of NSFR & 2011 & 2012 & 2013 & 2014 & 2015 & 2016 & Average value \\
\hline State-owned & NA & 0.0007 & -0.0150 & -0.0188 & -0.0206 & -0.0073 & -0.0122 \\
\hline Joint-stock & NA & -0.0402 & -0.0258 & -0.0272 & -0.0350 & -0.0468 & -0.0350 \\
\hline City & NA & -0.0020 & -0.0546 & -0.0142 & -0.0508 & 0.0298 & -0.0183 \\
\hline Listed & NA & -0.0209 & -0.0318 & -0.0221 & -0.0327 & -0.0200 & -0.0255 \\
\hline
\end{tabular}

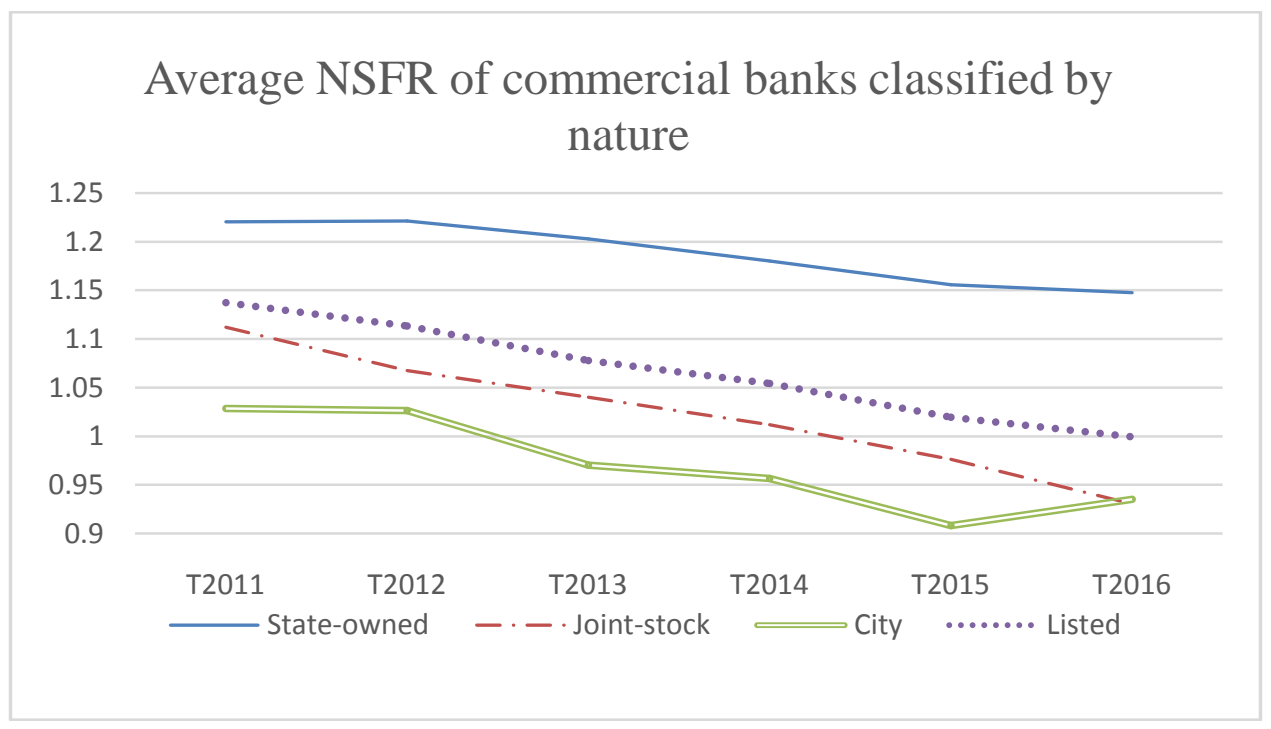

Figure 2 Average NSFR of commercial banks classified by nature

In Figure 2, not only the NSFR of listed city commercial banks increased in 2016, but also the NSFR of all kinds of listed commercial banks in China showed a downward trend year by year. Figure 3 shows the changes in the NSFR growth rates of various types of commercial banks. Among them, the NSFR growth rate of listed city commercial banks in 2013 is the lowest value in the range, in 2015, it is the second lowest value, the overall performance is "W" type. It reflects that China's listed city commercial banks in 2013 and 2015 do not meet the "Basel Agreement III" requirements for bank assets and liabilities maturity matching. The NSFR growth rate of state-owned commercial banks and listed joint-stock commercial banks in 2012 and 2016 changes in the opposite trend, from 2013 to 2015, the change trend of growth rate is consistent. The NSFR growth rate of listed jointstock commercial banks has been declining for three consecutive years since 2013. Listed joint-stock commercial banks are one of the three types of banks with the fastest decline in NSFR in 2016. The decline rate of NSFR in state-owned commercial banks has slowed down since 2015, and it has shown an increase in NSFR in 2016. 


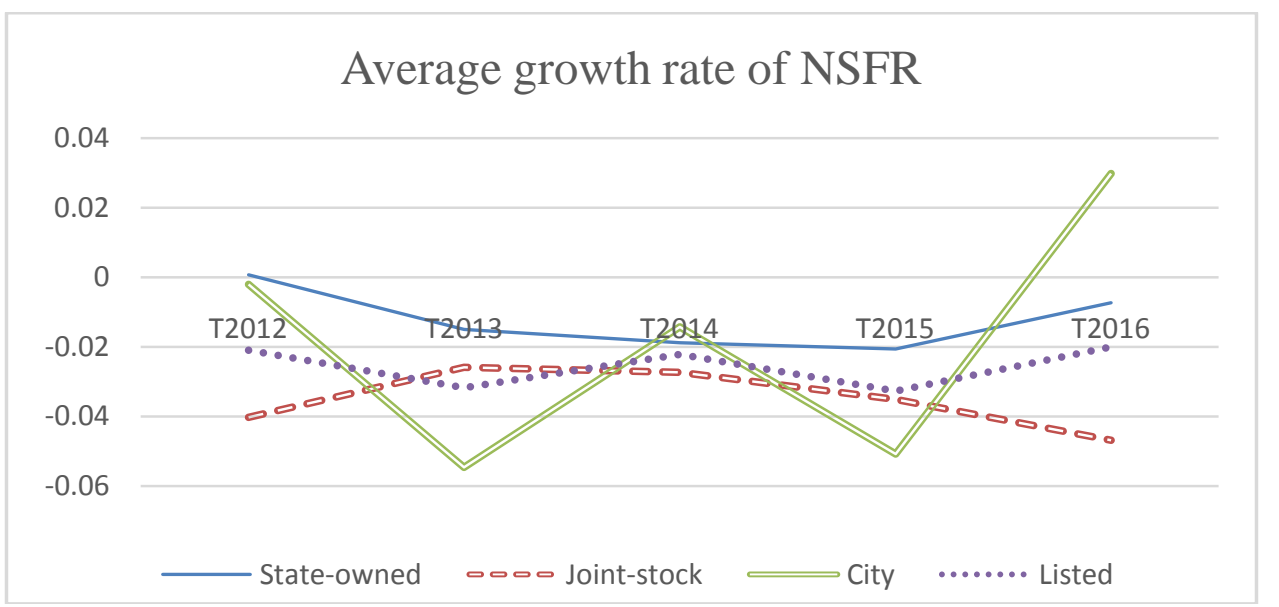

Figure 3 Average growth rate of NSFR of commercial banks classified by nature

By the end of 2016, according to the criterion of bank assets and liabilities maturity matching in Basel Agreement III, China's listed joint-stock commercial banks deviate fastest from the criterion, and the listed city commercial banks deviate most from the criterion. The whole banking industry is changing from relative abundance of liquidity to relative shortage of liquidity. Within the sample interval, the NSFR of all listed commercial banks declined at an average annual rate of 0.0255 . Among them, the listed joint-stock commercial banks declined the fastest, decreased by 0.0350 per year.

\section{Conclusions}

I. General observation on the liquidity of listed Commercial Banks in China

(I) The overall liquidity level of the listed commercial banks in China continues to decline

In 2011, the overall liquidity level of the listed commercial banks in China was relatively high. Except for the absence of the net steady finance ratio of the Bank of Ningbo, only the net steady finance ratio of Industrial Bank, Ping An Bank and Bank of Nanjing are less than 1, and the other 12 listed commercial banks have net stable financing ratios greater than 1 . However, in 2016, only these six listed commercial banks had net steady finance ratios greater than 1, including Bank for Economic Construction, Agricultural Bank of China, Industrial and Commercial Bank of China, Bank Of China, Bank of Communications, and China Merchants Bank. The other 10 listed commercial banks have net steady finance ratios of less than 1 . This shows that the long-term financing stability of most of the listed commercial banks in China is facing challenges.

Judging from the average net steady finance ratio of China's listed commercial banks from 2011 to 2016, the average net steady finance ratios of Shanghai Pudong Development Bank, Ping An Bank, China Everbright Bank, Industrial Bank, Bank of Nanjing and Bank of Ningbo are less than 1, indicating that the long-term stable assets of these banks are difficult to completely cover their long-term debt.

(II) The liquidity of different types of listed commercial banks in China is quite different

The long-term financing stability of listed state-owned commercial banks is higher than other listed commercial banks. From 2011 to 2016, the net steady finance ratio of listed state-owned commercial banks decreased gradually, but all of them were greater than 1 . The net steady finance ratio of listed joint-stock commercial banks began to be less than 1 in 2015, and decreased to less than 0.95 in 2016. The net steady finance ratio of listed city commercial banks has been less than 1 for 4 consecutive years since 2013. It shows that the long-term stable assets of listed state-owned commercial banks can completely cover their long-term debt, while the long-term stable assets of listed city commercial banks and listed joint-stock commercial banks can not completely cover their long-term debt. From the average growth rate of net steady finance ratio of listed commercial banks, the annual growth rate of net steady finance ratio of China's listed commercial banks is negative from 2012 to 2016. Compared with listed state-owned commercial banks and listed city commercial banks, the net steady finance ratio of listed joint-stock commercial banks has declined at a higher rate on average. Moreover, the decline rate of the net steady finance ratio of listed joint-stock commercial banks has continued to increase since 2013. The decline of net steady finance ratio of listed city commercial banks in 2013 is much larger than that of other banks from 2011 to 2016. The decline of the net steady finance ratio of listed city commercial banks in 2015 is much larger than that of other listed commercial banks in the same period. 


\section{References}

Basel Committee on Banking Supervision. Basel III: The Net Stable Funding Ratio[R]. BIS Working Paper No.295, 2014.

Discrimination and Control of Liquidity Risk of Deposit and Loan Liquidity Mismatch from the Perspective of Macro-prudence [J].Finance Manager Theory and Practice, 2014, (4): 2-8.

Zhang Chen, Han Wanghong. Bank liquidity, managerial optimism and bank risk taking [J].Journal of Modern Finance and Economics Tianjin University of Finance and Economics, 2013, (12): 74-85.

Zhang Sheeran, He Dexu. Monetary Policy Standpoint and Banking Risk-taking: An Empirical Study of China's Banking Industry [J]. Economic Research, 2012, (5): 31-44.

Lian Yonghui, Zhang Lin. Liquidity risk, bank structure liquidity and credit supply [J].International Finance Research, 2015, 339 (4): 636.

Liu Yan, Gong Changliang. Liquidity Risk Rating and Empirical Research of Commercial Banks [J].Systems Engineering, 2010, (12): 31-37.

Fu Qiang, Liu Xing, Jifang. Liquidity Risk Assessment of Commercial Banks [J]. Financial Forum, 2013, (4): 916.

Liu Xiaoxing. Liquidity and Stability of Financial System - Transmission Mechanism and Monitoring Research [M]. Beijing: Science Press, 2017:158-162.

Hong H, Huang J Z, Wu D. The information content of Basel III liquidity risk measures[J]. Journal of Financial Stability, 2014, 15:91-111.

Abdul-Rahman A, Sulaiman A A, Said N L H M. Does financing structure affects bank liquidity risk? [J]. PacificBasin Finance Journal, 2017.

Giordana G A, Schumacher I. Bank liquidity risk and monetary policy. Empirical evidence on the impact of Basel III liquidity standards[J]. International Review of Applied Economics, 2013, 27(5):633-655.

Wei X, Gong Y,Wu H M.The Impacts of Net Stable Funding Ratio Requirement on Banks' Choices of Debt Maturity[J].Journal of Banking \& Finance,2017,82(6):229-243.

Pan Min, Tao Yuou, Wang Yi. Is the long-term liquidity supervision of commercial banks procyclical? - Evidence from China's banking industry [J].International Finance Research, 2017, 360 (4): 76-85.

Gobat J., Yanase M.,Maloney J. F.The Net Stable Funding Ratio: Impact and Issues for Consideration[J].Social Science Electronic Publishing,2014,14(106):105-110. 